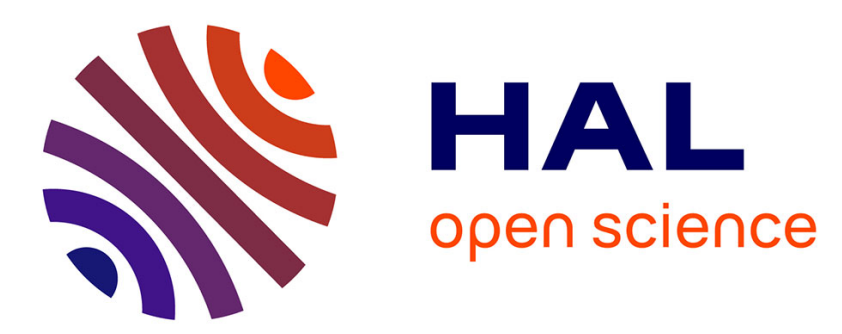

\title{
Combined US-ESR dating of fossil teeth from El Harhoura 2 cave (Morocco): New data about the end of the MSA in Temara region
}

Eslem Ben Arous, Christophe Falguères, Olivier Tombret, Mohamed Abdeljalil El Hajraoui, Roland Nespoulet

\section{- To cite this version:}

Eslem Ben Arous, Christophe Falguères, Olivier Tombret, Mohamed Abdeljalil El Hajraoui, Roland Nespoulet. Combined US-ESR dating of fossil teeth from El Harhoura 2 cave (Morocco): New data about the end of the MSA in Temara region. Quaternary International, 2020, 556, pp.88 95. 10.1016/j.quaint.2019.02.029 . hal-03015832

\section{HAL Id: hal-03015832 \\ https://hal.science/hal-03015832}

Submitted on 20 Nov 2020

HAL is a multi-disciplinary open access archive for the deposit and dissemination of scientific research documents, whether they are published or not. The documents may come from teaching and research institutions in France or abroad, or from public or private research centers.
L'archive ouverte pluridisciplinaire HAL, est destinée au dépôt et à la diffusion de documents scientifiques de niveau recherche, publiés ou non, émanant des établissements d'enseignement et de recherche français ou étrangers, des laboratoires publics ou privés. 


\section{Accepted Manuscript}

Combined US-ESR dating of fossil teeth from El Harhoura 2 cave (Morocco): New data about the end of the MSA in Temara region

Eslem Ben Arous, Christophe Falgueres, Olivier Tombret, Mohamed Abdeljali El Hajraoui, Roland Nespoulet

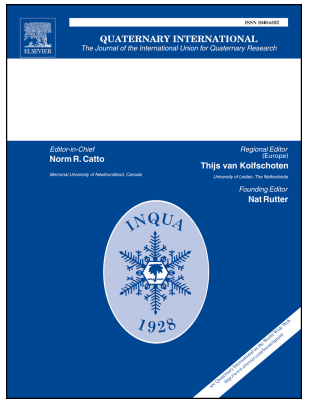

PII:

S1040-6182(18)31066-8

DOI:

https://doi.org/10.1016/j.quaint.2019.02.029

Reference: JQI 7770

To appear in: Quaternary International

Received Date: 20 September 2018

Revised Date: 18 February 2019

Accepted Date: 19 February 2019

Please cite this article as: Ben Arous, E., Falgueres, C., Tombret, O., El Hajraoui, M.A., Nespoulet, R., Combined US-ESR dating of fossil teeth from El Harhoura 2 cave (Morocco): New data about the end of the MSA in Temara region, Quaternary International (2019), doi: https://doi.org/10.1016/ j.quaint.2019.02.029.

This is a PDF file of an unedited manuscript that has been accepted for publication. As a service to our customers we are providing this early version of the manuscript. The manuscript will undergo copyediting, typesetting, and review of the resulting proof before it is published in its final form. Please note that during the production process errors may be discovered which could affect the content, and all legal disclaimers that apply to the journal pertain. 
4

Combined US-ESR dating of fossil teeth from El Harhoura 2 cave (Morocco): new data about the end of the MSA in Temara region.

\author{
Eslem BEN AROUS ${ }^{1}$, Christophe FALGUERES ${ }^{1}$, Olivier TOMBRET ${ }^{1}$, Mohamed \\ Abdeljalil EL HAJRAOUI ${ }^{2}$, Roland NESPOULET ${ }^{1}$ \\ 1: UMR7194, Muséum national d'histoire naturelle, 1, rue René Panhard, 75013, Paris, France \\ 2: Institut National des Sciences de l'Archéologie et du Patrimoine, Rabat, Morocco \\ Corresponding author: E. Ben Arous \\ Email: eslem.ben-arous@mnhn.fr
}

\begin{abstract}
The study of the Middle Stone Age (MSA) in North Africa is essential to better understand the human dispersals during the Late Pleistocene. The timing of the transition from the MSA to the Later Stone Age (LSA) in the region is still debated due to the scarcity of sites and the limited chronological constraints available. Among the few existing MIS 5 to MIS 1 archaeological sites in Northwestern Africa, El Harhoura 2 cave (Morocco) has been extensively excavated during the last decade. It has provided MSA and LSA sequences from which human remains have been systematically discovered in association with faunal and lithic assemblages.

The combined US-ESR method has been applied to date five teeth from layer 3 and 4A, which correspond to the most recent MSA occupations at El Harhoura 2 cave. The results suggest the disappearance of the MSA at this site to have occurred around $\sim 40 \mathrm{ka}$, at the end of MIS 3, which is consistent with the palaeoenvironmental interpretation derived from the faunal remains. These new results suggest that the last MSA human occupation are $\sim 15 \mathrm{ka}$ more recent than previously showed by OSL dating. Further investigation is required to fully understand the reason of such discrepancy between the two methods.
\end{abstract}

\title{
1. Introduction
}

During the last decades, research in Northwestern Africa has greatly improved the chronology of the North Africa Middle Stone Age (Barton et al., 2009, 2015; Dibble et al., 2012; Doerschner et al., 2016; El Hajraoui et al., 2012; Jacobs et al., 2011, 2012; Klasen et al., 2017; Mercier et al., 2007; Richter et al., 2017, 2010; Schwenninger et al., 2010). These dating results have contributed to highlight the importance of this region in the study of the origin and dispersal of anatomically modern humans within and out of Africa.

In North Africa, the end of the Late Pleistocene is marked by a cultural and subsistence shift from the Middle Stone Age (MSA) to the Later Stone Age (LSA). The nature and timing of this transition from MSA to LSA remains poorly known due to the paucity of reliable dating data and a lack of well-stratified sites. This results in a large age uncertainty for this transition, dated to between 60 and $25 \mathrm{ka}$. 
El Harhoura 2 cave (Fig.1), located in Rabat-Temara region (Morocco), is one the few sites in Northwestern Africa with a complete archeological sequence spanning from the MSA and the Neolithic (El Hajraoui et al., 2012). This coastal area is well known for its rich Middle to Late Pleistocene (MIS 5 to MIS 1) human fossil record. The MSA and LSA human occupations are documented in Dar-es-Soltane 1, Dar-es-Soltane 2, El Harhoura 2, El Mnasra and Contrebandiers caves. This area has also delivered most of MSA humans remains (Debénath, 2000; El Hajraoui et al., 2012). However, for some of the caves such as El Mnasra, the stratigraphic interpretation of the deposits is complicated by postdepositional perturbations (Lenoble, 2010). In contrast, the undisturbed archaeostratigraphic record observed at El Harhoura 2 makes the site a good candidate to chronologically constrain the disappearance of the MSA in the region.

In the present study, we applied the combined US-ESR dating method on hydroxyapatite from herbivore fossil teeth (Grün et al., 1988) to directly date human occupation at El Harhoura 2. These results will contribute to the refine the end of the MSA of Rabat-Temara sites.

\section{Geological, paleoenvironmental and archeological contexts}

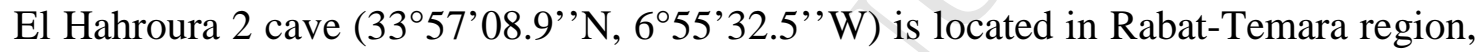
(Nespoulet et al., 2008; El Hajraoui et al., 2012). This karstic cave was dug in local calcarenites by the marine erosion of the Plio-Pleistocene coastal ridge, described as a succession of marine and continental deposits (Chahid et al., 2016). Located $300 \mathrm{~m}$ from the shoreline and $20.6 \mathrm{~m}$ above the present NGM (actual sea level), the site length is estimated to $22 \mathrm{~m}$, the depth around $9 \mathrm{~m}$ and the height $\sim 8 \mathrm{~m}$. El Harhoura 2 was discovered in 1977 and a preliminary excavation was conducted mainly in the entrance area (El Hajraoui et al. 2012). A first test pit of $8 \mathrm{~m}^{2}$ was established in 1996, followed by a lateral extension excavated in 2007, which allowed to describe the complete archeological sequence at the entrance of the cave. In 2012, the excavation was further extended to cover a total area of more than $200 \mathrm{~m}^{2}$.

The sedimentary cave infilling is homogenous and dominated by sandy-clay matrix (Boudad et al., 2017). Four sedimentary units (Fig.2-A) were identified from bottom to top. Unit I is dominated by grey sandy clays. Unit II is defined by a higher proportion of clays and a lower content of silts. Unit III is described as an intermediate unit between clay and carbonates and the Unit IV described by a lower content of sands.

Archeostratigraphy (Fig.2-A) has been mainly described from the test-pit of the entrance area and subdivided into eleven levels (El Hajraoui et al., 2012). Level 1 (Neolithic), level 2 (LSA), levels 3, 4, 6, 8 (MSA). Other levels (5, 7, 9, 10 and 11) were excavated only on a small surface $\left(<3 \mathrm{~m}^{2}\right)$. For a total number of $n=687$ lithic artefacts founded in the MSA levels, this number is less than $\mathrm{n}=14$ for levels 5, 7, 9, 10 and 11 (El Hajraoui et al., 2012, p.92). In the current state of excavations, these levels are considered as archeologically sterile. Only the levels 3 and 4 are studied in this paper. The MSA industries of these levels are composed by Levallois and micro-Levallois knapping tools, laminar artifacts, side-scrapers and chopping tools. No tanged tools, characteristic of the Aterian, have been recovered, even in extensively excavated areas. Humans burials were 
found in the level 1 and 2 and post-cranial isolated bones were found on the levels 3 and 9 (El Hajraoui et al., 2012).

Taphonomic studies on abundant and well-preserved micro-faunal remains confirm that no major disturbance occurred in these accumulations, and demonstrate the integrity of the archeological levels (Stoetzel et al., 2011). Zooarcheological studies (Campmas et al., 2015) show a diversified faunal assemblage (presence of Alcelaphinae, Equidae, Bovinae and Rhinocerotidae). Faunal spectrum is dominated by Gazella sp. which represent $>70 \%$ of the number of identified specimens (NISP) in levels 3 and 4A (and almost 57\% in level 8). There is also a presence of carnivores (between $10 \%$ and $16 \%$ of the NISP for the levels 3 and 4A), which appear to be the main accumulators of large mammal remains in levels 2 to 5 (Campmas et al., 2015). These observations, combined with results from the lithic analysis (Stoetzel et al., 2014), show that human occupations in these levels were short and non-intensive. Considering palaeoenvironmental reconstructions, both large and small vertebrate assemblages from the whole archeological sequence show a succession of relatively humid (levels 3, 4A, 6 and 8) and arid (levels 2, 5 and 7) phases (Stoetzel et al., 2011, 2014).

\section{Material and methods}

Five fossil teeth (Fig.2-B-C) of Equidae (Equus sp.) and Bovidae (Gazella sp.) were selected for dating analyses from the Institut National des Sciences de l'Archéologie et du Patrimoine (INSAP, Rabat) collections (three from level 3, one near the limit between levels 3 and 4A and one from level 4A). These teeth were collected during excavations conducted between 2004 and 2010. Combined US-ESR dating analyses were performed at the Geochronology laboratory of the Museum National d'Histoire Naturelle (MNHN) in Paris.

Fossil teeth were prepared following the protocol described in Wagner et al. (2010). Dental tissues (enamel, dentine, cement) were mechanically separated. Enamel samples were cleaned using a dental drill then ground and sieved to 100-200 $\mu \mathrm{m}$. Depending on the amount of enamel powder available, each sample was split into 8,9 or 10 aliquots $(\sim 50 \mathrm{mg}$ each) and irradiated using a ${ }^{60}$ Co $\gamma$-ray source at LABRA (CEA, Saclay, France) in 2014. ESR measurements were carried out at room temperature using EMX X-band Bruker spectrometer and the following acquisition parameters: 5 scans, 1024 points resolution, $1.013 \mathrm{~mW}$ microwave power, $9.80 \mathrm{GHz}$ microwave frequency, $100 \mathrm{kHz}$ modulation frequency, $0.1 \mathrm{mT}$ modulation amplitude, $20.48 \mathrm{~ms}$ conversion time and $5.12 \mathrm{~ms}$ time constant. The ESR measurements were repeated 4 times for each aliquot over different days. ESR intensities were extracted using the Bruker WINEPR System software from the asymmetric ESR signal between the T1-B2 (Grün, 1998) and normalized by the weight of each aliquot. Average ESR intensities form the repeated measurements were used for the evaluation of the equivalent dose $\left(D_{e}\right)$ determination.

$D_{e}$ values (Table 1) were obtained by fitting a single saturated exponential (SSE) function through the experimental data points (Yokoyama et al., 1985; Duval and Grün, 2016). Fitting was performed with Origin Pro8 software, with data weighted by the inverse of the squared ESR intensity (Grün and Brumby, 1994). All ESR dose response curves are 
provided in Fig.1 SM. An example of ESR spectrum is displayed in Fig.2 SM. This spectrum shows a non-horizontal baseline which may potentially impact the $\mathrm{D}_{\mathrm{e}}$ (Duval and Martín-Francés, 2017). This was evaluated on one sample (EH2-2730) by performing a baseline correction (using a cubic function) for each aliquot measured.

Alpha-ray spectrometry U-series analyses (Table 2) were carried out at the Musée de l'Homme U-series laboratory. Samples (0.3-1 g) were dissolved in $\mathrm{HNO}_{3}(7 \mathrm{~N})$ and spiked with ${ }^{233} \mathrm{U},{ }^{236} \mathrm{U}$ and ${ }^{229} \mathrm{Th}$ and charged onto anion exchange resin AG $1 \times 8$ (100-200 mesh chloride form) in order to separate and purify $U$ and Th sources (Shao et al., 2011). The columns were rinsed with $\mathrm{HCl}(0.1 \mathrm{~N})$ to collect uranium and purified using a UTEVA resin column (Horwitz et al., 1992) in $\mathrm{HNO}_{3}(7 \mathrm{~N})$. Th was eluted with $\mathrm{HCl}(8 \mathrm{~N})$. The purified $U$ and Th were then evaporated by mixing TTA/benzene solution and deposed on an iron disk covered by aluminum paper. Alpha counting was run for 8 days.

Dose rate provided on Table 1 was determined in situ (Table 3) using a $\gamma$-ray portable spectrometer Inspector 1000 Canberra with NaI detector and following the threshold technique (Mercier and Falguères, 2007). Additional high resolution $\gamma$ spectroscopy measurements were performed at the Geochronology laboratory (Paris) on raw sediment samples (Fig.2-C, Table SM.1), using a high resolution low-background Ge detector, to determine the external $\beta$-dose rate from specific activity of $\mathrm{U}, \mathrm{Th}$, and $\mathrm{K}$. Analyses were performed on about $90 \mathrm{~g}$ of homogenized sediment samples sealed in a plastic box during at least three weeks to ensure radon equilibrium.

The cosmic dose was evaluated according to Prescott and Hutton (1994). The spatial configuration of the cave in different orientations (North, South, West and East) was taken into account with a 3D model as in Richard et al. (2017).

Moisture content was measured in the laboratory by drying at $40^{\circ} \mathrm{C}$ for ten days. The water content was estimated form the weight difference sediment before and after drying. Sediments presented low water contents, below $5 \%$, which are quite similar to values presented by Jacobs et al. (2012). However, we suspect these values may underestimate the long-term water content, as sediment samples were collected in summer (June 2014) in relatively dry conditions (archeological sections exposed to sunlight). Consequently, we assumed instead a higher value of $10 \pm 5 \%$ for age calculation (Grün, 1989).

Combined US-ESR ages were calculated using DATA program (Grün, 2009) and the following parameters: $\alpha$-efficiency of $0.13 \pm 0.02$ (Grün and Katzenberger-Apel, 1994), a water content of $5 \pm 3 \mathrm{wt} \%$ in dentine and cement and null in the enamel. $\beta$-attenuation factors are from Brennan et al. (1997) and dose rate conversion factors from Guérin et al., (2011). Age results are given at $1 \sigma$ confidence level. A cement/enamel/dentine configuration was used for the age calculation of sample EH2-2993, whereas we used a sediment/enamel/dentine configuration for the other samples.

\section{Results and discussion}


Equivalent doses, doses rates, $p$-values, and US-ESR ages calculated for each sample are given in Table 1. U-series data and enamel thickness are presented in Table 2.

\section{U-series data}

Uranium content in the enamel ranges between 0.170 and $0.060 \mathrm{ppm}$, i.e. close to the detection limits of $\alpha$-ray spectrometry (see Falguères et al., 2018). U-content in cement and dentine is between 4 and 8 ppm. ${ }^{234} \mathrm{U} /{ }^{238} \mathrm{U}$ ratios are systematically higher than 1 in dentine and cement tissues. In enamel, this ratio is associated with large relative errors (between 10 and 20\%), particularly for samples in which $U$ content is very low. P-values for dental tissues are superior than -1 and ${ }^{230} \mathrm{Th} /{ }^{234} \mathrm{U}$ values are lower than unity (between 0.03 and $0.81)$ : they suggest that there is no uranium leaching in the dental tissues.

\section{Radioelements content}

Specific activities of ${ }^{238} \mathrm{U},{ }^{226} \mathrm{Ra},{ }^{222} \mathrm{Rn}$ and ${ }^{232} \mathrm{Th}$ in the surrounding sediments are presented on Table SM.1. No significant disequilibrium in the U-238 decay chain is observed for EH2-sed 1 and EH2-sed 2 sediments. In contrast, a $17 \%$ loss of Ra and $26 \%$ of Rn-loss observed for EH2-sed 3 sample. The origin of these disequilibria is unknown.

\section{Equivalent doses}

$D_{e}$ values range between 20 and 31 Gy. The ESR spectrum displayed in Fig.SM.2 of the sample EH2-2730 presents a non-horizontal baseline. A sensitivity test performed on sample EH2-2730 shows that baseline correction has, however, a very limited impact on the $D_{e}$ value $(<3 \%)$. Following Duval and Grün (2016), the influence of the maximum irradiation dose $\left(D_{\max }\right)$ on the $D_{\mathrm{e}}$ estimate was also evaluated by successively removing the last irradiation points (until 220-240 Gy). Results displayed in Fig.SM.4 show a minor impact of $D_{\max }$ in the present data set, as the difference between each resulting $D_{e}$ does not exceed the error range. Finally, repeated measurements $(n=4)$ show relatively limited variability of the individual $\mathrm{D}_{\mathrm{e}}$ values derived from each independent measurement $(<8 \%$ for a given sample; Table SM.3). All these evidence consistently illustrate the robustness of the ESR data set collected.

\section{Dose rate}

Results show that 3/4 teeth display homogeneous dose rates, except for EH2-2993 sample that exhibits a lower value by about $10 \%$. This difference could be explained by the presence in this tooth of a cement layer, which produced a lower $\beta$ dose rate compared to that from the surrounding sediment.

Gamma dose rates significantly contribute to the total dose rate by 50-60\% (Table 1, Fig. SM.3), while cosmic dose rates represent $15-20 \%$ of the total dose rate. Consequently, 
these two parameters significantly impact the age calculation. The correspondence between sediment and in situ measurements with tooth samples is specified in table SM.1. The comparison of our data with in situ gamma dose rates measured by Jacobs et al. (2012) and those measured with TL-dosimeters by Janati-Idrissi et al., (2012) does not a show significant variability (Table 3). For level 3, values overall range from $368.3 \pm 18.4$ to $310.0 \pm 15.5 \mu \mathrm{Gy} / \mathrm{a}$. The present work and Jacobs et al. (2012) obtained mean values of $363.9 \pm 18.2$ and $346.7 \pm 17.3 \mu \mathrm{Gy} / \mathrm{a}$, respectively, which representing a variability $<5 \%$. Similar observations can be made for level 4A: values range from $348.0 \pm 17.4$ to $385.4 \pm$ $19.3 \mu \mathrm{Gy} / \mathrm{a}$, with a variability of about $10 \%$ (Table 3 ). As these mean in situ gamma values are very close to the individual in situ measurements, the latter were chosen to calculated ages. To evaluate the potential impact of the moisture content on the calculated age, simulations were performed by taking into account different moisture content $(3 \pm 1 \%, 5 \pm$ $1 \%, 8 \pm 3 \% 10 \pm 5 \%$ ). Some of water content, as $3 \pm 1 \%, 5 \pm 1,6 \pm 2 \%, 7 \pm 2$ and $9 \pm$ $2 \%$ have been used by Jacobs et al. (2012). Results are summarized on Fig.SM.5 and show a difference of $<1 \%$. Consequently, whatever the water content used (between 3 and 10 $\%)$, the moisture content has virtually no impact on the calculated ages.

\section{Combined US-ESR ages}

Combined US-ESR range from 39 to $48 \mathrm{ka}$ for the level 3 (with a mean age of $43.7 \pm$ $4.5 \mathrm{ka})$ and from 46 to $49 \mathrm{ka}$ for the level $4 \mathrm{~A}$.

EU-ESR ages, considered as minimum ages (Table SM.2), were also calculated using DATA software for comparison. EU-ESR results are very close to US-ESR ages, with differences ranging between 3 and $6 \mathrm{ka}$ (between 7-15\% of variability). This is due to the fact that uranium content in dental tissue from El Harhoura 2 samples generated low dose rate from teeth (accounting for 1-15\% of the total dose rate, Fig. 2 SM). Consequently, Uuptake modelling has a negligible impact on the calculated ages, as often expected for Late Pleistocene tooth samples (Richard, 2015). Combined US-ESR age results appear to be overall stratigraphically consistent.

\section{Comparison with previous results}

Our ages are in agreement with previous combined US-ESR results obtained by JanatiIdrissi et al. (2012) for the level 4A but they are younger than previous OSL dates. Only two of OSL ages overlap with the combined US-ESR ages for the level 3 (Fig.3). Indeed, OSL ages locating the age of the latest MSA human occupations around $57 \pm 4 \mathrm{ka}$ as a mean age (Jacobs et al., 2012) and the age of the level 4A at $74 \pm 4$ ka.

Regarding these data, the difference observed cannot be explained by the gamma dose rates, which are quite similar for ESR and OSL samples. Considering the equivalent doses, many remarks can be made. First of all, the $D_{e}$ values determined using SG-SAR protocol by Jacobs et al. (2012) lead to the identification of 2-3 quartz grain populations using Finite Mixture Model (FMM). The presence of different components could be explained 
either as mixing grains from underlying/overlying levels even if "mixing mechanism is not clear", or "by the effect of variations in the beta dose rate to individual grains" (Jacobs et al., 2012, p.385-386). It is difficult to understand the meaning of these different population grains in term of geology. In fact, the sedimentary processes in karstic coastal caves of this area are not well understood in terms of chronology and origin, due to the impossibility to differentiate quartz from different origins (aeolian, marine, peeling of the cave)(Niftah et $a l ., 2005)$. The final OSL $\mathrm{D}_{\mathrm{e}}$ chosen for age calculation correspond to the quartz grain population statistically well represented (for level 3, between $63.7 \pm 4.7$ to $48.5 \pm 5 \%$ of representation). Consequently, the resulting OSL age estimates are about $20 \%$ higher than our combined US-ESR ages. Using instead the $\mathrm{D}_{\mathrm{e}}$ from the less representative quartz grain population (between $5.0 \pm 2.7$ to $19.2 \pm 4.2 \%$ of representation) would allow to recalculate OSL ages between $\sim 19 \mathrm{ka}$ and $38 \mathrm{ka}$ for level 3. For the level $4 \mathrm{~A}, \mathrm{D}_{\mathrm{e}}$ from the less representative quartz grain population $(8.7 \pm 3.7 \%$ of representation) provides an OSL age of about $42 \mathrm{ka}$. This result would be closer to the combined US-ESR ages.

The discrepancy of $\sim 20 \%$ between previous OSL ages (Jacobs et al., 2012) and combined US-ESR ages could also be explained by an underestimation of the $D_{e}$ values obtained for the fossil teeth, due to the presence of unstable radicals in the hydroxyapatite as observed in Joannes-Boyau and Grün (2011) and Richter et al. (2017) on enamel fragment. However, ESR dose estimate were carried out in the present study on enamel powder, which results in randomly spatial distribution of the enamel crystals that renders difficult such a comparison. The impact on these unstable components remains nevertheless unclear and needs to be further investigated. It is indeed sample dependent, and some teeth are simply not affected by this issue (e.g. Dirks et al., 2017).

Combined US-ESR ages presented in this work suggest that the last MSA occupation in Rabat-Temara is dated to around $40 \mathrm{ka}$. Other Northwestern African sites display similar chronologies for late MSA occupations: $29 \mathrm{ka}$ using radiocarbon method in Taforalt (Barton et al., 2015) and 30.9 $\pm 2.5 \mathrm{ka}$ with OSL (Weisrock et al., 2008) for the end of MSA without tanged tools at Wadi Noun.

In contrary, others sequences in the Rabat-Temara region show different chronologies: for example, the latest MSA in Contrebandiers cave is older than $90 \mathrm{ka}$ by OSL and $70 \mathrm{ka}$ by TL (Dibble et al., 2012). However, erosion surface and the disruption in the deposits of the Contrebandiers cave (Aldeias et al., 2014) limit the discussion. Nevertheless, these combined US-ESR ages of El Harhoura 2 cave match with previous TL ages obtained for the end of MSA in El Harhoura 1 cave placed between $32.15 \pm 4.8 \mathrm{ka}$ and $41.16 \pm 3.5 \mathrm{ka}$ (Debénath et al., 1986).

\section{Conclusion}

The numerical ages obtained in the present study correlate the latest MSA human occupations at El Harhoura 2 to the end of the MIS 3 (Fig.3). This attribution is in good agreement with paleoenvironmental data derived from the study of micro fauna (Stoetzel et al., 2011), which position these levels in humid phase and associated to a tree-filled meadow environment.

Combined US-ESR dating of fossil teeth provides a direct chronological constraint on the archaeological levels at El Harhoura 2 and suggest that the latest MSA human 
occupation may have occurred at least $15 \mathrm{ka}$ after the OSL ages previously estimated by Jacobs et al. (2012). The origin of the discrepancy between the results from the two methods should however be further investigated in the future.

The direct dating of the last MSA human occupation at El Harhoura 2 cave provides an important contribution to a better understanding of the timing of Late Pleistocene human dispersals in the coastal environments of Northwestern Africa. Future investigations at Rabat-Temara sites should focus on both the revision of old chronological data and new dating application studies of well-identified and well-contextualized archeological material in order to improve the existing chronological framework of the area.

\section{Acknowledgements}

Authors thank to A. Akerraz, director of INSAP, for access to the faunal collections from EL Harhoura 2 in 2014. We also thank J.-J. Bahain and E. Stoetzel for their constructive helpful discussion/advices. The authors are grateful to three anonymous reviewers for constructive and useful comments on an earlier version of this article.

\section{References}

Aldeias V, Goldberg P, Dibble HL and El-Hajraoui M, 2014, Deciphering site formation processes through soil micromorphology at Contrebandiers Cave, Morocco. Journal of Human Evolution. Elsevier Ltd 69(1): 8-30, DOI: 10.1016/j.jhevol.2013.12.016.

Barton RNE, Bouzouggar A, Collcutt SN, Carrión Marco Y, Clark-Balzan L, Debenham NC and Morales J, 2015, Reconsidering the MSA to LSA transition at Taforalt Cave (Morocco) in the light of new multi-proxy dating evidence. Quaternary International 114, DOI: 10.1016/j.quaint.2015.11.085.

Barton RNE, Bouzouggar A, Collcutt SN, Schwenninger JL and Clark-Balzan L, 2009, OSL dating of the Aterian levels at Dar es-Soltan I (Rabat, Morocco) and implications for the dispersal of modern Homo sapiens. Quaternary Science Reviews. Elsevier Ltd 28(1920): 1914-1931, DOI: 10.1016/j.quascirev.2009.03.010.

Boudad L, El Hammouti K, Chahid D, Nespoulet R and El Hajraoui A, 2017, Les indices climatiques du Pléistocène supérieur et de l'Holocène des formations quaternaires de la côte atlantique (Rabat-Témara, Maroc). Anthropologie (France). Elsevier Masson SAS 121(1-2): 90-101, DOI: 10.1016/j.anthro.2017.03.007.

Brennan BJ, Rink WJ, McGuirl EL, Schwarcz HP and Prestwich WV, 1997, Beta doses in tooth enamel by "one-group" theory and the ROSY ESR dating software. Radiation Measurements. Pergamon 27(2): 307-314, DOI: 10.1016/S1350-4487(96)00132-1.

Campmas E, Michel P, Costamagno S, Amani F, Stoetzel E, Nespoulet R and El Hajraoui MA, 2015, Were Upper Pleistocene human/non-human predator occupations at the Témara caves (El Harhoura 2 and El Mnasra, Morocco) influenced by climate change? Journal of Human Evolution. Elsevier Ltd 78: 122-143, DOI: 10.1016/j.jhevol.2014.08.008.

Chahid D, Boudad L, Lenoble A, Hmaidi A El, Chakroun A and Jacobs Z, 2016, Nouvelles données morpho-stratigraphiques et géochronologiques sur le cordon littoral externe ( SIM 5-c ) de Rabat - Témara , Maroc. Géomorphologie : relief, processus, 
environnement.

Debénath A, 2000, Le peuplement préhistorique du Maroc: données récentes et problèmes. L'anthropologie 104: 131-145, DOI: 10.1016/S0003-5521(00)90006-2.

Debénath A, Raynal J-P, Roche J, Texier JP and Ferembach D, 1986, Stratigraphie, habitat, typologie et devenir de l'Atérien marocain : données récentes. L'anthropologie 90(2): 233-246.

Dibble HL, Ández EA, Blackwell BAB, Hallett-desguez E, Lin SAMC, Meyer MC and Steele TE, 2012, New Excavations at the Site of Contrebandiers Cave, Morocco. PaleoAnthropology 145-201, DOI: 10.4207/PA.2012.ART74.

Dirks PH, Roberts EM, Hilbert-Wolf H, Kramers JD, Hawks J, Dosseto A, Duval M, Elliott M, Evans M, Grün R, Hellstrom J, Herries AI, Joannes-Boyau R, Makhubela T V, Placzek CJ, Robbins J, Spandler C, Wiersma J, Woodhead J and Berger LR, 2017, The age of Homo naledi and associated sediments in the Rising Star Cave, South Africa. eLife 6, DOI: $10.7554 /$ eLife.24231.

Doerschner N, Fitzsimmons KE, Ditchfield P, McLaren SJ, Steele TE, Zielhofer C, McPherron SP, Bouzouggar A and Hublin J-J, 2016, A New Chronology for Rhafas, Northeast Morocco, Spanning the North African Middle Stone Age through to the Neolithic. Plos One 11(9): e0162280, DOI: 10.1371/journal.pone.0162280.

Duval M and Grün R, 2016, Are published ESR dose assessments on fossil tooth enamel reliable? Quaternary Geochronology 31: 19-27, DOI: 10.1016/j.quageo.2015.09.007.

Duval M and Martín-Francés L, 2017, Quantifying the impact of $\mu$ CT-scanning of human fossil teeth on ESR age results. American Journal of Physical Anthropology. John Wiley \& Sons, Ltd 163(1): 205-212, DOI: 10.1002/ajpa.23180.

El Hajraoui MA, Nespoulet R, Debénath A and Dibble H, 2012, Préhistoire de la région de Rabat-Témara.

Falguères C, Ghaleb B, Tombret O, Ben Arous E, Richard M, Moigne AM, Saos T, Frouin M, Caparros M and Barroso-Ruiz C, 2018, ESR/U-series dates on Equus teeth from the Middle Pleistocene Acheulean site of Cueva del Angel, Spain. Quaternary Geochronology. Elsevier, DOI: 10.1016/J.QUAGEO.2018.02.003.

Grün R, 1989, Electron spin resonance (ESR) dating. Quaternary International (1): 65109.

Grün R, 1998, Reproducibility measurements for ESR signal intensity and dose determination: High precision but doubtful accuracy. Radiation Measurements, DOI: 10.1016/S1350-4487(98)00014-6.

Grün R, 2009, The relevance of parametric U-uptake models in ESR age calculations. Radiation Measurements. Elsevier Ltd 44(5-6): 472-476, DOI: 10.1016/j.radmeas.2009.02.011.

Grün R and Brumby S, 1994, The assessment of errors in past radiation doses extrapolated from ESR/TL dose-response data. Radiation Measurements 23: 307-315.

Grün R and Katzenberger-Apel O, 1994, An alpha-irradiator for ESR dating. Ancient TL (12): 35-38.

Grün R, Schwarcz HP and Chadam J, 1988, ESR dating of tooth enamel: Coupled 
correction for U-uptake and U-series disequilibrium. International Journal of Radiation Applications and Instrumentation. Part 14(1-2): 237-241, DOI: 10.1016/13590189(88)90071-4.

Guérin G, Mercier N and Adamiec G, 2011, Dose-rate conversion factor: update. Ancient TL 29(1): 5-8.

Horwitz EP, Dietz ML, Rhoads SM, Chiarizian R, Diamond H, Essling AM and Graczyk D, 1992, Separation and preconcentration of lead from acidic media by extraction chromatography. Analytica Chimica Acta 266: 25-37.

Jacobs Z, Meyer MC, Roberts RG, Aldeias V, Dibble H and El Hajraoui MA, 2011, Single-grain OSL dating at La Grotte des Contrebandiers ("Smugglers" Cave'), Morocco: Improved age constraints for the Middle Paleolithic levels. Journal of Archaeological Science. Elsevier Ltd 38(12): 3631-3643, DOI: 10.1016/j.jas.2011.08.033.

Jacobs Z, Roberts RG, Nespoulet R, El Hajraoui MA and Debénath A, 2012, Single-grain OSL chronologies for Middle Palaeolithic deposits at El Mnasra and El Harhoura 2, Morocco: Implications for Late Pleistocene human-environment interactions along the Atlantic coast of northwest Africa. Journal of Human Evolution 62(3): 377-394, DOI: 10.1016/j.jhevol.2011.12.001.

Janati-Idrissi N, Falguères C, Haddad M, Nespoulet R, Abdeljalil M, Hajraoui EL, Debénath A, Bejjit L, Bahain J, Michel P, Garcia T, Boudad L, Hammouti K El and Oujaa A, 2012, Datation Par ESR-U/Th combinéesde dents fossiles des Grottes d'El Mnasra et D’ El Harhoura 2 , région de Rabat-Témara. Implications chronologiques sur le peuplement du Maroc Atlantique au Pléistocène Supérieur et son environnement. Quaternaire 23(1): 25-35.

Joannes-Boyau R and Grün R, 2011, A comprehensive model for CO2- radicals in fossil tooth enamel: Implications for ESR dating. Quaternary Geochronology. Elsevier 6(1): 8297, DOI: 10.1016/J.QUAGEO.2010.09.001.

Klasen N, Kehl M, Mikdad A, Brückner H and Weniger G-C, 2017, Chronology and formation processes of the Middle to Upper Palaeolithic deposits of Ifri n'Ammar using multi-method luminescence dating and micromorphology. Quaternary International. Elsevier Ltd and INQUA 1-14, DOI: 10.1016/j.quaint.2017.10.043.

Lenoble, A., 2010. Lithostratigraphie de la grotte d'El Mnasra. Description et hypothèses proposées. In: El Hajraoui, M.A., Nespoulet, R. (Eds.), Mission Archéologique El Harhoura-Témara, pp. 14e15. Programme de coopération: Ministére de la Culture (Rabat), Ministére des Affaires Etrangéres et Européennes (Paris), Unpublished.

Lisiecki LE and Raymo ME, 2005, A Pliocene-Pleistocene stack of 57 globally distributed benthic d180 records. Paleoceanography 20(1): 1-17, DOI: 10.1029/2004PA001071.

Mercier N and Falguères C, 2007, Field gamma dose-rate measurement with a $\mathrm{NaI}(\mathrm{Tl})$ detector: re-evaluation of the "threshold" technique. Ancient TL 25(1): 1-4.

Mercier N, Wengler L, Valladas H, Joron JL, Froget L and Reyss JL, 2007, The Rhafas Cave (Morocco): Chronology of the mousterian and aterian archaeological occupations and their implications for Quaternary geochronology based on luminescence (TL/OSL) age determinations. Quaternary Geochronology 2(1-4): 309-313, DOI: 10.1016/j.quageo.2006.03.010. 
Nespoulet R, El Hajraoui MA, Amani F, Ben Ncer A, Debénath A, Idrissi A, Lacombe JP, Michel P, Oujaa A and Stoetzel E, 2008, Palaeolithic and neolithic occupations in the Témara region (Rabat, Morocco): Recent data on hominin contexts and behavior. African Archaeological Review 25(1-2): 21-39, DOI: 10.1007/s10437-008-9025-1.

Niftah S, Debénath A and Miskovsky J-C, 2005, Origine du remplissage sédimentaire des grottes de Témara (Maroc) d'après l'étude des minéraux lourds et l'étude exoscopique des grains de quartz. Quaternaire 16(2): 73-83.

Prescott JR and Hutton JT, 1994, Cosmic ray contributions to dose rates for luminescence and ESR dating: Large depths and long-term time variations. Radiation Measurements. Pergamon 23(2-3): 497-500, DOI: 10.1016/1350-4487(94)90086-8.

Richard M, 2015, Chronologie des occupations humaines au Pléistocène supérieur dans le Jura Souabe, Allemagne et dans les vallées de la Saône et du Rhône, France, par les méthodes de la résonance de spin électronique et des séries de l' uranium, ESR / U-Th.

Richter D, Grün R, Joannes-Boyau R, Steele TE, Amani F, Rué M, Fernandes P, Raynal JP, Geraads D, Ben-Ncer A, Hublin J-J and McPherron SP, 2017, The age of the hominin fossils from Jebel Irhoud, Morocco, and the origins of the Middle Stone Age. Nature 546(7657): 293-296, DOI: 10.1038/nature22335.

Richter D, Moser J, Nami M, Eiwanger J and Mikdad A, 2010, New chronometric data from Ifri n'Ammar (Morocco) and the chronostratigraphy of the Middle Palaeolithic in the Western Maghreb. Journal of Human Evolution. Elsevier Ltd 59(6): 672-679, DOI: 10.1016/j.jhevol.2010.07.024.

Schwenninger J-L, Collcutt SN, Barton N, Bouzouggar A, Clark-Balzan L, El Hajraoui MA, Nespoulet R and Debénath A, 2010, A New Luminescence Chronology for Aterian Cave Sites on the Atlantic Coast of Morocco. In: Garc (ed) South-Eastern Mediterranean Peoples Between 130, 000 and 10, 000 Years Ago, 18-36.

Shao Q, Bahain J-J, Falguères C, Peretto C, Arzarello M, Minelli A, Thun Hohenstein U, Dolo J-M, Garcia T, Frank N and Douville E, 2011, New ESR/U-series data for the early Middle Pleistocene site of Isernia la Pineta, Italy. Radiation Measurements. Pergamon 46(9): 847-852, DOI: 10.1016/J.RADMEAS.2011.03.026.

Stoetzel E, Campmas E, Michel P, Bougariane B, Ouchaou B, Amani F, El Hajraoui MA and Nespoulet R, 2014, Context of modern human occupations in North Africa: Contribution of the T??mara caves data. Quaternary International. Elsevier Ltd and INQUA 320: 143-161, DOI: 10.1016/j.quaint.2013.05.017.

Stoetzel E, Marion L, Nespoulet R, El Hajraoui MA and Denys C, 2011, Taphonomy and palaeoecology of the late Pleistocene to middle Holocene small mammal succession of El Harhoura 2 cave (Rabat-Témara, Morocco). Journal of human evolution 60(1): 1-33, DOI: 10.1016/j.jhevol.2010.07.016.

Wagner GA, Krbetschek M, Degering D, Bahain J-J, Shao Q, Falgueres C, Voinchet P, Dolo J-M, Garcia T and Rightmire GP, 2010, Radiometric dating of the type-site for Homo heidelbergensis at Mauer, Germany. Proceedings of the National Academy of Sciences 107(46): 19726-19730, DOI: 10.1073/pnas.1012722107.

Weisrock A, Rousseau L, Reyss JL, Falguères C, Ghaleb B, Bahain JJ, Beauchamp J, Boudad L, Mercier N, Mahieux G, Pozzi JP, Janati-Idrissi N and Ouammou A, 2008, Travertins de la bordure nord du Sahara Morocain: Dispositifs morphologiques, datations 
478 U/Th et indications paléoclimatiques. Geomorphologie: Relief, Processus, Environnement

479 (3): 153-168, DOI: 10.4000/geomorphologie.6793.

480 Yokoyama Y, Falguères C and Quaegebeur JP, 1985, ESR dating of quartz from

481 Quaternary sediments : first attempts. Nuclear Tracks (10): 921-928.

482

483

$484 \quad$ Figure captions

485

486

487

488

489

490

491

492

493

494

495

496

497

498

499

500

501

502

503

504

505

506

507

508

509

510

511

512

513

514

515

516

517

518

519

Figure 1: Location of El Harhoura 2 cave in Rabat-Temara region, Northwestern Africa (Map modified from El Hajraoui et al., 2012).

Figure 2: Synthetic stratigraphy (A) of the El Harhoura 2 site (modified from El Hajraoui et al., 2012), including the location of the relative area where the sediments and tooth samples come from (B), their depth distribution projected on the North-South profile (C). Photo: R. Nespoulet and C. Falguères.

Figure 3: Synthesis of the US-ESR and OSL ages obtained for the level 3 and 4A opposite to the $\delta^{18} \mathrm{O}$ data from Lisiecki and Raymo (2005).

\section{Table captions}

Table 1: Equivalent dose $\left(\mathrm{D}_{\mathrm{e}}\right)$, Dose rate and combined US-ESR age estimation presented at $1 \sigma$ confidence level. Key: $\mathrm{e}=$ enamel; $\mathrm{d}=$ dentine; $\mathrm{c}=$ cement. The dose rate components presented are: internal dose rate $(\alpha+\beta$ of the enamel), $\beta 1$ (beta contribution from the dentine), $\beta 2$ (beta contribution from cement or sediment), gamma and cosmic dose rates.

Table 2: U-series data obtained by alpha-spectrometry analyses of El Harhoura 2 tooth samples. Data are presented with $2 \sigma$. Key: $\mathrm{D}=$ dentine; $\mathrm{C}=$ cement; $\mathrm{E}=$ enamel; side 1 =dentine and side 2 =sediment or cement. For enamel in low U-content, isotopic ratios (italic) are associated with large relative errors (between 10 and 20\%).

Table 3: In situ gamma dosimetry measured with a NaI detector (Jacobs et al., 2012; this work) and TL dosimeters (Janati-Idrissi et al., 2012) in levels 3 and 4A. A mean value was calculated for each level. Error associated to mean value is the mean of error. A 5\% error was assumed for each individual measurement. For level 3, $5 \%$ variability was estimated from the two mean values $(346.7 \pm 17.3$ and $363.9 \pm 18.2)$. For level $4 \mathrm{~A}, 10 \%$ variability was estimated from the two values presented $(370.0 \pm 18.5$ and $348.0 \pm 17.4)$; *: initial value given was $438 \mu \mathrm{Gy} / \mathrm{a}$ and the cosmic dose rate of $90 \mu \mathrm{Gy} / \mathrm{a}$ was subtracted from this value. 


\section{Supplementary material}

Table SM.1: ${ }^{238} \mathrm{U},{ }^{226} \mathrm{Ra},{ }^{222}-\mathrm{Rn},{ }^{232} \mathrm{Th}$ and ${ }^{40} \mathrm{~K}$ content (dpm/g or \%) measured and converted using dose rate factors published in Guérin et al. (2011). Sample EH2-sed 3 has been measured but not used on this calculation because of its geographical distance from the teeth samples.

Table SM.2: EU-ESR and combined US-ESR ages comparison for tooth samples dated in this work. Errors are displayed at $1 \sigma$.

Table SM.3: $D_{e}$ values over the repeated ESR measurements $(n=4)$. The dispersion of the induvial $\mathrm{D}_{\mathrm{e}}$ per sample is not significantly important and remains rarely more than $\sim 8 \%$ (< 3 Gy). RSD: relative standard deviation. Data are associated with $1 \sigma$.

Figure SM.1: ESR dose response curve for samples dated in this work computing by Origin Pro 8 software, using SSE function (Yokoyama et al., 1985; Duval and Grün, 2016). All $D_{\mathrm{e}}$ presented range between 20 and $31 \mathrm{~Gy}$.

Figure SM.2: ESR spectra measured in sample EH2-2730.

Figure SM.3: proportion of the different dose rate components. Key: Iinternal $=$ dose rate $\alpha$ $+\beta$ contribution from the enamel, $\beta 1=$ beta contribution from the dentine, $\beta 2=$ beta contribution from cement or sediment.

Figure SM.4: Evolution of $D_{e}$ as a function of $D_{\max }$ for all samples fitted with a SSE function. $1 \sigma$ errors are displayed. The $D_{e}$ value used for the US-ESR calculation is shown with a dash line.

Figure SM.5: recalculated combined US-ESR ages in taking account different water content of $3 \pm 1 \%, 5 \pm 1 \%, 8 \pm 3 \%$ and $10 \pm 5 \%$. 


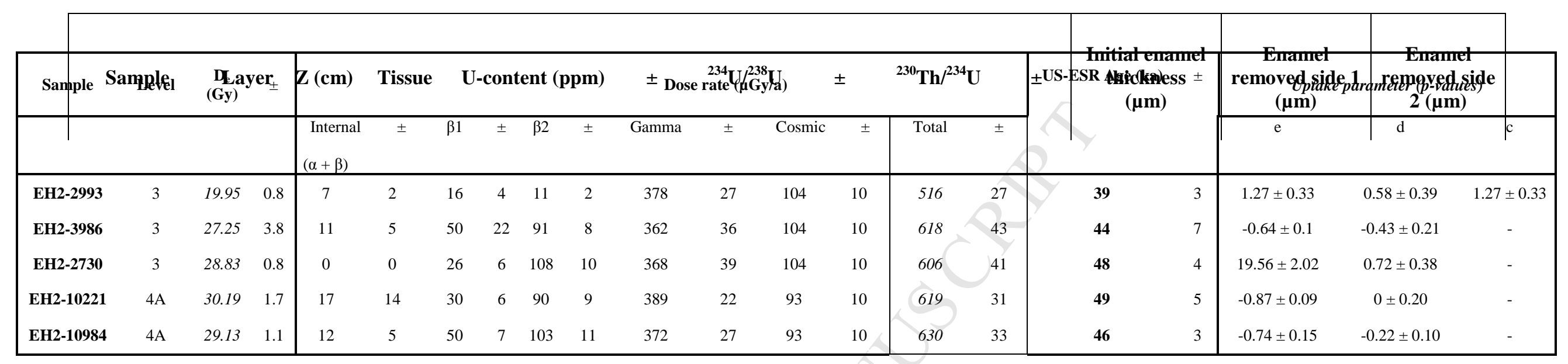

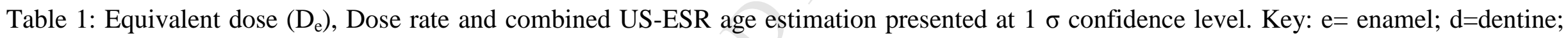
$\mathrm{c}=$ cement. The dose rate components presented are: internal dose rate $(\alpha+\beta$ of the enamel), $\beta 1$ (beta contribution from the dentine), $\beta 2$ (beta contribution from cement or sediment), gamma and cosmic dose rates. 


\begin{tabular}{|c|c|c|c|c|c|c|c|c|c|c|c|c|}
\hline \multirow[t]{3}{*}{ EH2-2993 } & 3 & \multirow{3}{*}{-415} & $\mathrm{D}$ & 4.72 & 0.17 & 1.05 & 0.04 & 0.13 & 0.01 & \multirow[b]{3}{*}{$830 \pm 83$} & \multirow[b]{3}{*}{$39 \pm 4$} & \multirow[b]{3}{*}{$57 \pm 6$} \\
\hline & & & $\mathrm{C}$ & 4.78 & 0.22 & 1.14 & 0.06 & 0.03 & 0.03 & & & \\
\hline & & & $\mathrm{E}$ & 0.17 & 0.02 & 0.94 & 0.14 & 0.09 & 0.09 & & & \\
\hline \multirow[t]{2}{*}{ EH2-3986 } & \multirow[t]{2}{*}{3} & \multirow{2}{*}{-426} & $\mathrm{D}$ & 7.90 & 0.47 & 1.05 & 0.06 & 0.29 & 0.06 & & & \\
\hline & & & $\mathrm{E}$ & 0.06 & 0.01 & 0.90 & 0.21 & 0.25 & 0.82 & $720 \pm 72$ & $43 \pm 4$ & $94 \pm 9$ \\
\hline \multirow[t]{2}{*}{$E H 2-2730$} & \multirow[t]{2}{*}{3} & \multirow{2}{*}{-437} & $\mathrm{D}$ & 7.44 & 0.44 & 1.06 & 0.06 & 0.14 & 0.02 & & & \\
\hline & & & $\mathrm{E}$ & 0.07 & 0.01 & 1.29 & 0.26 & 0.03 & 0.16 & $690 \pm 69$ & $53 \pm 5$ & $40 \pm 5$ \\
\hline \multirow[t]{2}{*}{ EH2-10221 } & \multirow[t]{2}{*}{$4 \mathrm{~A}$} & \multirow{2}{*}{-458} & $\mathrm{D}$ & 6.59 & 0.29 & 1.05 & 0.05 & 0.75 & 0.17 & & & \\
\hline & & & $\mathrm{E}$ & 0.15 & 0.04 & 1.05 & 0.35 & 0.81 & 0.32 & $710 \pm 71$ & $92 \pm 9$ & $64 \pm 6$ \\
\hline \multirow[t]{2}{*}{ EH2-10984 } & \multirow[t]{2}{*}{$4 \mathrm{~A}$} & \multirow{2}{*}{-470} & $\mathrm{D}$ & 7.98 & 0.31 & 1.16 & 0.05 & 0.18 & 0.02 & & & \\
\hline & & & $\mathrm{E}$ & 0.09 & 0.02 & 0.72 & 0.24 & 0.67 & 0.38 & $700 \pm 70$ & $58 \pm 6$ & $54 \pm 5$ \\
\hline
\end{tabular}

Table 2: U-series data obtained by alpha-spectrometry analyses of El Harhoura 2 tooth samples. Data are presented with $2 \sigma$. Key: $D=$ dentine; $C=$ cement; $\mathrm{E}=$ enamel; side 1 =dentine and side 2 =sediment or cement. For enamel in low U-content, isotopic ratios (italic) are associated with large relative errors (between 10 and 20\%).

Gamma Dose rate $(\mu \mathrm{Gy} / \mathbf{a})$ 


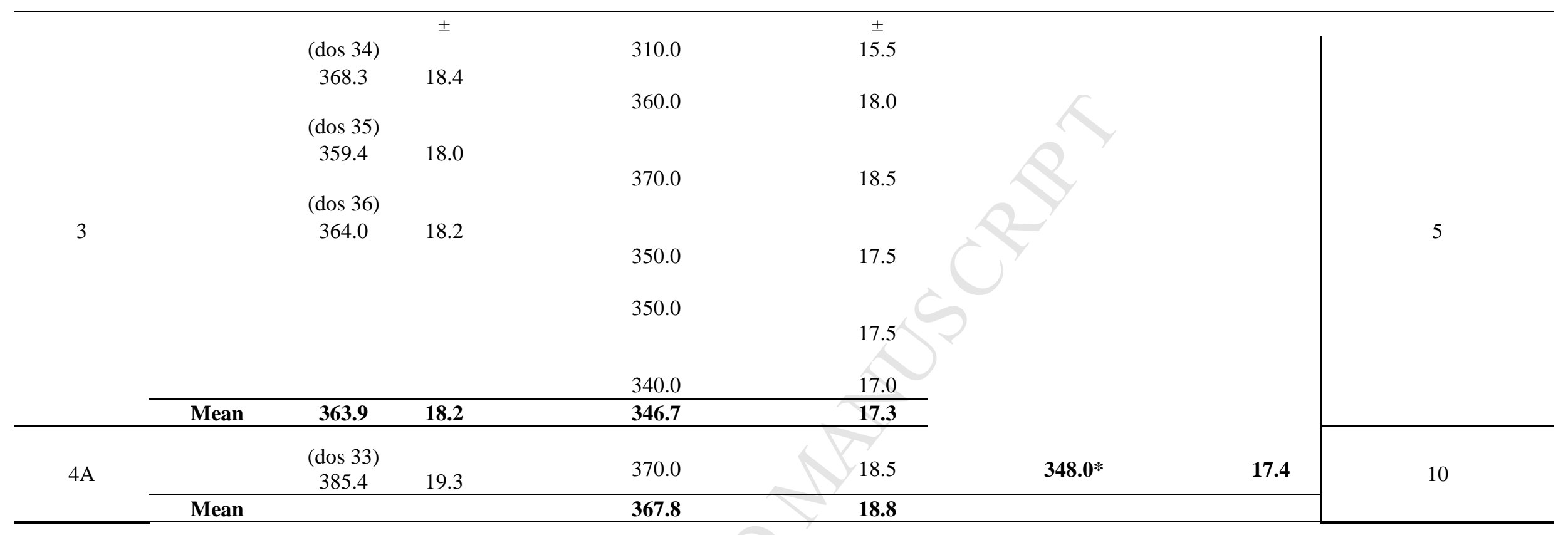

Table 3: In situ gamma dosimetry measured with a NaI detector (Jacobs et al., 2012; this work) and TL dosimeters (Janati-Idrissi et al., 2012) in levels 3 and 4A. A mean value was calculated for each level. Error associated to mean value is the mean of error. A 5\% error was assumed for each individual measurement. For level 3, $5 \%$ variability was estimated from the two mean values $(346.7 \pm 17.3$ and $363.9 \pm 18.2)$. For level $4 \mathrm{~A}, 10 \%$ variability was estimated from the two values presented ( $370.0 \pm 18.5$ and $348.0 \pm 17.4)$; *: initial value given was $438 \mu \mathrm{Gy} / \mathrm{a}$ and the cosmic dose rate of $90 \mu \mathrm{Gy} / \mathrm{a}$ was subtracted from this value. 


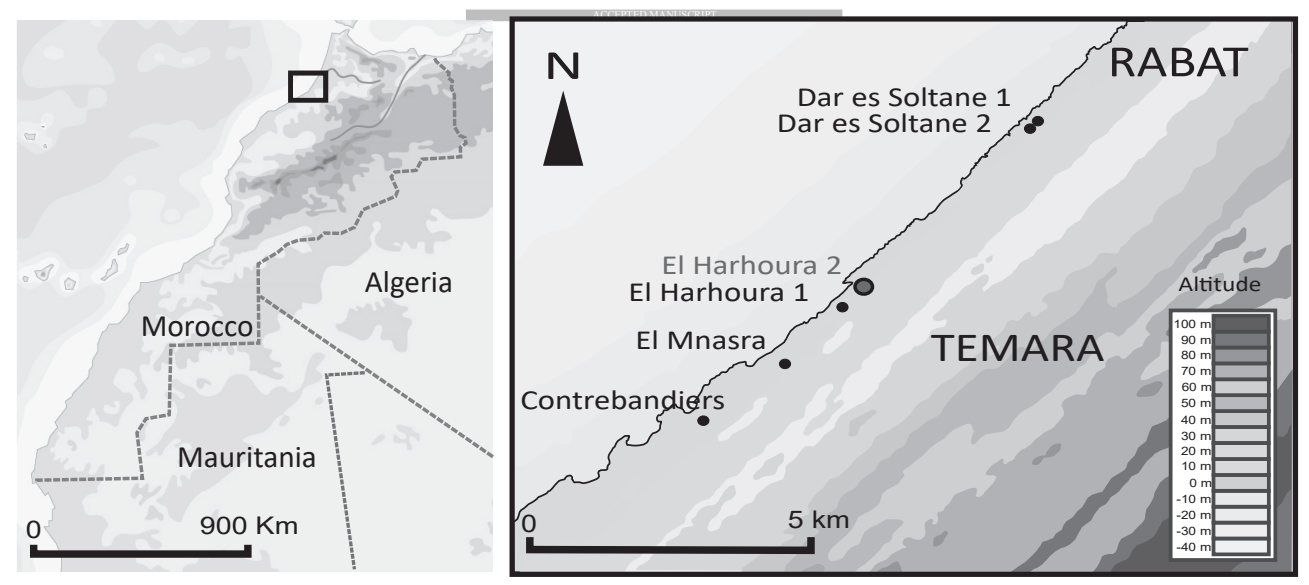




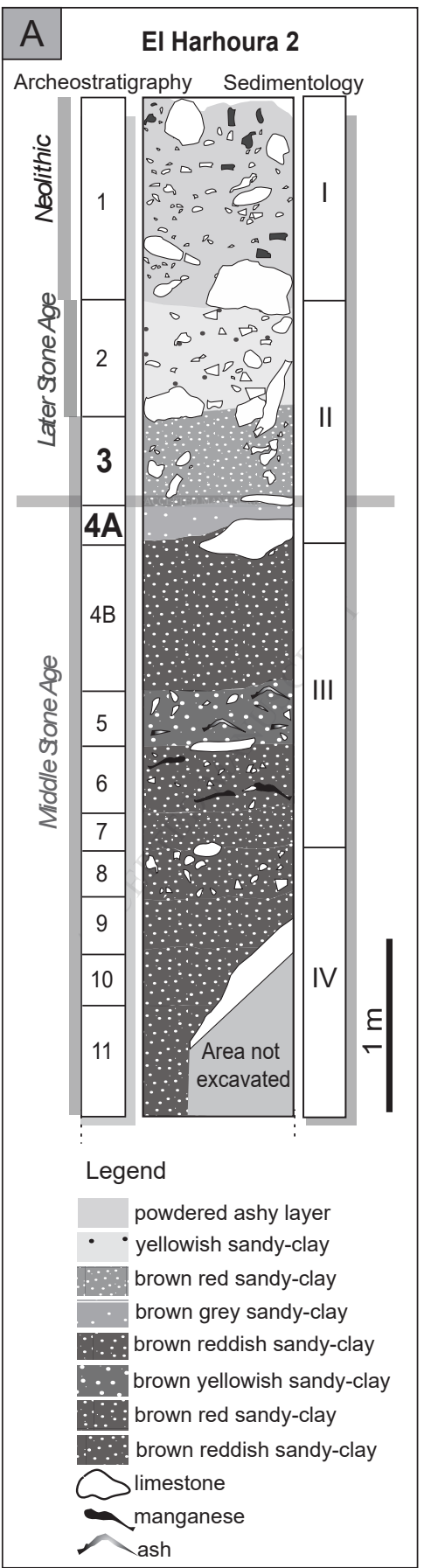




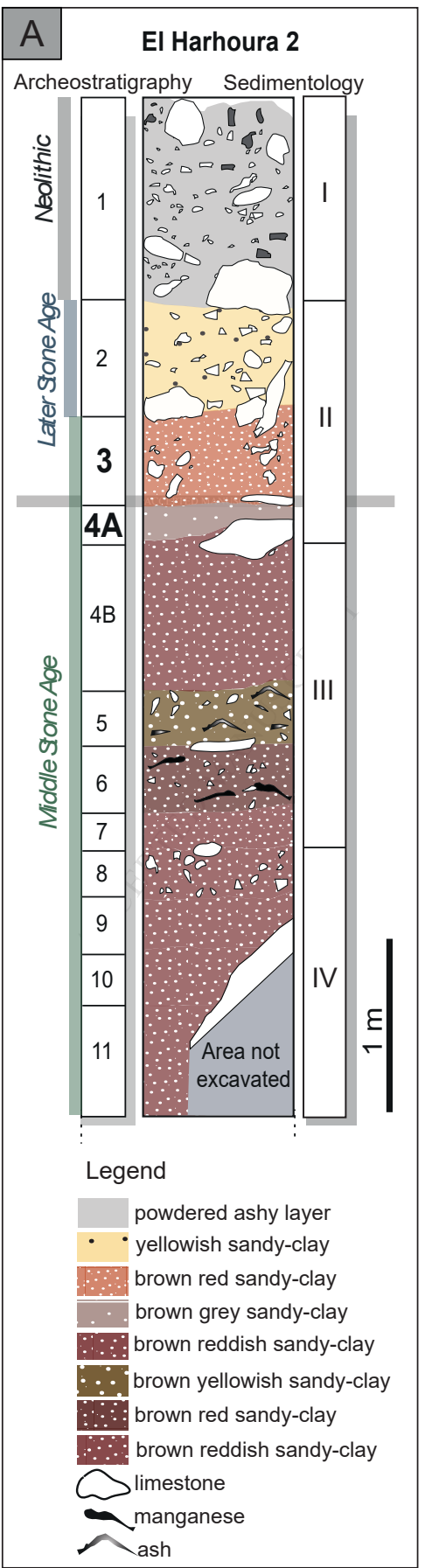


